\title{
S100P, a peculiar member of S100 family of calcium-binding proteins implicated in cancer
}

\author{
V. TÓTHOVÁ, A. GIBADULINOVÁ*
}

\begin{abstract}
Department of Molecular Medicine, Institute of Virology, Slovak Academy of Sciences, Dúbravská cesta 9,
\end{abstract} 84505 Bratislava, Slovak Republic

\begin{abstract}
Summary. - S100P belongs to several members of the S100 family of calcium-binding proteins, associated with malignant phenotype. Altered levels of S100P expression have been described at different stages and types of cancer. Transcriptional regulation involves different pathways activated by glucocorticoids, growth factors and bone morphogenic factor via the corresponding receptors. Signals coming from these pathways appear to be transmitted through ERK1/2 (extracellular-signal regulated kinase) and mediated presumably by STAT, SMAD, NFkB transcription factors. The secreted form of S100P can bind to extracellular ligand-binding site of RAGE (receptor for advanced glycation end-products), and via activation of ERK/MAPK pathway can influence gene expression, cell proliferation and survival. In addition, S100P interacts and modulates the activity of several targets with multiple binding modes and simultaneous coordination of further target proteins in larger multiprotein complexes, e.g. scaffolding proteins -IQGAP1 and ezrin, known to promote and regulate signal transduction pathways. The majority of S100P binding partners are proteins involved in cytoskeletal dynamics, and their physical interactions with S100P lead to defects in cellular morphogenesis and tissue disruption, the acquisition of uncontrolled migratory and invasive features. Finally, the evidence for S100P role in cancer metastasis opens a new direction for the future research efforts.
\end{abstract}

Keywords: S100P; diagnostics and prognosis; multiprotein complexes; gene regulation; metastasis

\section{Contents:}

1. Lost in evolution

2. Expression - significance for diagnostics and prognosis

3. Association with metastasis, contribution to metastatic cascade

4. Role in larger multiprotein complexes, interactions and implications in tumor phenotype

5. Gene regulation of S100P expression

5.1 Promoter analysis

6. Future prospects

*Corresponding author. E-mail: virugiba@savba.sk ; phone: +4212-59302441.

Abbreviations: $\mathrm{AhR}=$ aryl hydrocarbon receptor; $\mathrm{DX}=\mathrm{dex}-$ amethasone; GR = glucocorticoid receptor; GRE = GR element; ICAM $=$ intercellular adhesion molecule; NSCLC $=$ non-small cell lung cancer; $\mathrm{PDA}=$ pancreatic ductal adenocarcinoma

\section{Lost in evolution}

$\mathrm{S} 100 \mathrm{P}$ protein is a member of the $\mathrm{S} 100$ family calciumbinding proteins which function as extracellular and/or intracellular regulators of diverse cellular processes and participate in various human pathologies. Designation " $P$ " indicates that human placenta was the organ of the first isolation (Becker et al., 1992; Emoto et al., 1992), S100 stands for "Soluble in 100\% saturated ammonium sulphate solution" (Moore, 1965).

Gene S100P (similar to S100B, G and Z) is as a single copy located on chromosome different from majority S100A(1-17) genes that are as double copies clustered in the genome. All known S100 genes are found only in vertebrates which may mean that S100 proteins are evolutionarily young (Shang et al., 2008). S100P gene is absent even in mice and rats suggesting that it could has evolved from an ancestral gene different from that of the S100A gene cluster.

Individual S100 proteins are expressed in a cell-specific manner depending on environmental factors and functional 
role(s), so the relatively large number of family members is not simply due to redundancy, as they are not exchangeable (Donato, 2003). No enzymatic activity has been ascribed to any member of the $\mathrm{S} 100$ family.

S100 proteins are probably an example of calciummodulated regulatory proteins that intervene in the fine tuning of a relatively large number of specific intracellular and (in the case of some members) extracellular activities. Functional interactions determine activities as well as the distribution of S100P from the nuclei to the cytoplasm and to the extracellular matrix.

S100P protein has received increasing attention due to accumulating evidence of its significant role during the development and progression of different cancers. Since its first association with human prostate cancer (Averboukh et al., 1996), a number of microarray and immunohistochemical studies have shown that S100P transcription and protein expression correlate with characteristic features of malignant phenotype in various types of tissues. Recent reports on direct reprogramming of cancer cells (in study recapitulation of the cancer phenotype) which results in reduced tumorigenic potential revealed downregulation of S100P (Mahalingam et al., 2012).

\section{Expression - significance for diagnostics and prognosis}

Altered levels of S100P expression have been described in different stages and types of cancer (Table 1).

In breast cancer, $\mathrm{S} 100 \mathrm{P}$ protein was connected with immortalization and tumor progression (Guerreiro Da Silva et al., 2000; Schor et al., 2006). Survival of breast cancer patients with S100P positive carcinomas was significantly (by about sevenfold) worse and positive staining for S100P correlated with two other metastasis-inducing proteins, S100A4 and osteopontin (Wang et al., 2006). S100P was prominent among PEGA "paracrine-independent expression of grade-associated" genes overexpressed in high-grade breast tumors. Silencing markedly diminished coregulated gene transcripts and reversed aggressive tumor behavior (Dairkee et al., 2009).

Significantly overexpressed S100P was detected in pancreatic cancer (Crnogorac-Jurcevic et al., 2003; Deng et al., 2008; Dowen et al., 2005; Logsdon et al., 2003; Missiaglia et al., 2004; Ohuchida et al., 2006; Bournet et al., 2012). Its up-regulation was found to represent an early event in pancreatic carcinogenesis and was correlated with an increasing grade of pancreatic intraepithelial lesions (Ohuchida et al., 2006). Use of S100P in cytologically borderline cases can increase the diagnostic accuracy in diagnosis and staging of pancreatic adenocarcinoma (Dim et al., 2011), particularly in difficult cases of well-differentiated PDA versus reactive ductal epithelium (Kosarac et al., 2011).
S100P could be considered a biomarker for aggressive, hormone-refractory (Amler et al., 2000; Mousses et al., 2002) and metastatic prostate cancer and could also serve as a potential drug target or a chemosensitization target (Basu et al., 2008).

The expression of S100P has been analyzed in cholangiocarcinoma (Hamada et al., 2010) and patients with S100P-positive peripheral intrahepatic cholangiocarcinoma were more likely to have poor prognoses than those with S100P-negative tumors (Tsai et al., 2012).

Colorectal cancer patients with normal serum levels of S100P showed favorable prognoses compared with patients with elevated S100P levels which predicts colorectal cancer liver metastases (Ding et al., 2011) and S100P was verified to claim a poor clinical outcome of gastric cancer patients (Jia et al., 2009).

Immunohistochemical profile S100P distinguished pure urothelial carcinomas (positive for S100P 93\%) with an opposite pattern to pure squamous cell carcinomas (Gulmann et al., 2012). An important difference was described between lung adenocarcinoma metastatic to the bladder and primary bladder adenocarcinoma (Raspollini et al., 2010).

The possible development of S100P into a cancer biomarker and prognostic indicator has been proposed for certain tumor types. However, S100P expression is not restricted to neoplastic cells, but is also detectable in various normal cell types. This fact must be carefully considered when planning diagnostic and therapeutic applications based on S100P targeting (Parkkila et al., 2008).

\section{Association with metastasis, contribution to metastatic cascade}

Overexpression of S100P has been shown to promote metastasis in diverse cancer models. S100P was associated with metastatic phenotype in prostate tumors (Mousses et al., 2002), with significant induction of metastasis in rat mammary model (Wang et al., 2006) and metastasizing tumors non-small cell lung cancer (Diederichs et al., 2004). $\mathrm{S} 100 \mathrm{P}$ increased angiogenesis and metastasis formation from subcutaneous xenotransplants of NSCLC cells, whereas small hairpin RNA interference against S100P prevented metastasis formation in mice (Bulk et al., 2008). Furthermore, $\mathrm{S} 100 \mathrm{P}$ has been identified as a gene with expression levels differentially regulated in the anoikis-resistant cell lines (Kupferman et al., 2007).

S100P gene was found to be highly expressed in a cohort of human hepatic metastases with primary colorectal tumors (Ding et al., 2011) and its nuclear expression in aggressive peripheral-type intrahepatic cholangiocarcinoma significantly correlated with vascular and lymphatic invasion and lymph node metastasis (Aishima et al., 2011). 
Deeper insight into the molecular mechanisms underlying the functional roles of this protein in the metastatic spread was gained by the team around T. Crnogorac-Jurcevic. They showed that the role of S100P in the invasion of pancreatic cancer cells is mediated through cytoskeletal changes and regulation of cathepsin D protease (Whiteman et al., 2007). Moreover, overexpression of S100P led to changes in the expression levels of several cytoskeletal proteins (including cytokeratins 8,18 , and 19) and to disorganization of the actin cytoskeleton network as well as changes in the phosphorylation status of the actin regulatory protein cofilin. S100PBP (S100P binding partner, that shows no homology to any described protein) significantly mediates adhesion through regulation of cathepsin $\mathrm{Z}$ and integrins in pancreatic cancer cells (Lines et al., 2012). S100P-increased transendothelial migration of pancreatic ductal adenocarcinoma cancer cells in vitro was also confirmed in vivo experiments using a zebrafish embryo model (Barry et al., 2012).

Further elucidation of S100P-induced metastasis has been provided by Du et al. (2012). Their study shows that S100P physically interacts in vivo with non-muscle myosin NMIIA molecules of the acto-myosin cytoskeleton, partially dissociates its filaments and causes their more peripheral redistribution. These changes are accompanied by a redistribution and significant decrease of focal adhesion sites (FAS), consequently cell adhesion is reduced and cell migration is enhanced (Du et al., 2012).

The prometastatic role of S100P had been proposed also due to its direct binding to and activation of ezrin. The resulting activation of ezrin can promote the transendothelial migration of tumor cells. The link to tumor cell migration is most noticeable in highly metastatic tumors (Austermann et al., 2008).

Ezrin is a cytoskeletal protein that binds to cell surface glycoproteins such as CD44 and ICAMs, through interacting with their $(\mathrm{N})$-terminal domains and to filamentous actin through its (C)-terminal domains. One of the functions of ezrin is to participate in the formation of cell-surface complexes that mediate cell-cell and cellextracellular matrix attachments. Among the components of these adhesion complexes are E-cadherin and integrins. An imbalance in the signals from CD44 and E-cadherin due to ezrin overexpression substitutes for E-cadherin loss and decreased cellular adhesion (Hunter, 2004). RNA-interfering down-regulation of ezrin significantly reduces the spontaneous migration of carcinoma cells (Rossy et al., 2007).

As outlined below, BMP-4 is an active component of epithelial-mesenchymal transition, an important phenomenon preceding acquisition of metastatic phenotype, and therefore regulation of S100P via BMP-4 might explain association of $\mathrm{S} 100 \mathrm{P}$ with increased migration, invasion, and metastasis.

\section{Role in larger multiprotein complexes, interactions and implications in tumor phenotype}

S100 proteins function due to interactions and modifications of target proteins in a calcium-bound state. Divalent calcium cations induce conformational changes in their affinity for interacting partners and thereby promote homo- or hetero-oligomerization of S100 proteins apart from S100A10, which has lost its ability to coordinate calcium ions due to alterations in both of its calcium-binding sites (Gerke and Weber, 1985). Individual S100 proteins differ in the structural flexibility of the target-binding sites essential for recognition of diverse targets, consequently interactions and modulating activity of various targets contribute to extremely broad functional diversity of S100 proteins (Permyakov et al., 2011).

On the other hand multiple binding modes and a great deal of flexibility suggests that simultaneous coordination of more than a single target protein by some $\mathrm{S} 100$ proteins and the role of S100 proteins in larger multiprotein complexes (Rezvanpour and Shaw, 2009).

S100P has been identified as one of the ezrin ligands. S100P binding to N-terminal domain of dormant ezrin unmasks the F-actin binding site (Koltzscher et al., 2003). The resulting activation of ezrin can promote the transendothelial migration of tumor cells. It has therefore been proposed that via this interaction ezrin and S100P exert their prometastatic functions (Austermann et al., 2008).

Ezrin-mediated linking of the cell membrane to actin cytoskeleton allows a cell to interact with its microenvironment and provides an "intracellular scaffolding" that facilitates signal transduction through a number of growth factor receptors and adhesion molecules (Meng et al., 2010). Ezrin involvement of a Rho/ROCK-dependent signaling pathway (Ivetic and Ridley, 2004) and also the potential roles of ezrin in VEGF-induced signaling cascade Ezrin/Calpain/PI3K/ AMPK/ /eNOS (Youn et al., 2009) have been reported.

Another target protein of dimeric S100P is IQGAP1 (Heil et al., 2011), a scaffolding multi-domain protein that functions in signal transduction pathways and regulates cytoskeletal function by integrating multiple targets, including Cdc42, actin (Erickson et al., 1997) and calmodulin (Ho et al., 1999). Ca2+/S100P selectively interferes with the IQGAP1-dependent MAPK activation as a negative feedback regulator (Heil et al., 2011).

A prominent position among the S100P interacting proteins is held by the receptor for advanced glycation endproducts (RAGE) that binds secreted S100P. RAGE can bind multiple ligands implicated in various diseases, including several members of the $\mathrm{S} 100$ protein family, such as S100A12, S100A1, S100B, and S100P (Arumugam et al., 2004; Donato, 2007; Hofmann et al., 1999). S100P-RAGE interaction leads to activation of extracellular-regulated kinases (ERK) and NF-kappaB signaling consistently with increased cell 
proliferation, migration, survival and tumor growth. These effects can be blocked by agents that interfere with RAGE suggesting that S100P can act in an autocrine manner via RAGE (Arumugam et al., 2005; Fuentes et al., 2007).

Additional binding partners of S100P have been identified using co-immunoprecipitation and affinity chromatography, respectively. These include S100P binding protein S100PBPR (Dowen et al., 2005), and CacyBP/SIP, a calcyclin and Siah-1interacting protein that can bind several S100 family members (Filipek et al., 2002). Noteworthy, CacyBP/SIP has been identified as a regulatory component of a novel ubiquitinylation complex involved in $\beta$-catenin degradation (Matsuzawa and Reed, 2001) and it is very possible that its interaction with S100P could be involved in the modulation of this process.

S100P contributes to increased cell proliferation and survival via both intracellular and extracellular actions, but in addition contributes to defects in cellular morphogenesis that lead to tissue disruption and the acquisition of inappropriate migratory and invasive characteristics (Fig. 1).

\section{Gene regulation of S100P expression}

S100 proteins are expressed in a tissue- and cell-specific manner and up- or downregulation is usually characteristic of a given type of cancer and considered as a marker of a malignant state.

Hypomethylation of cancer-promoting genes is an important molecular mechanism involved in tumor development (McCabe et al., 2009) and also changes in S100 protein expression in cancer are in many cases, due to epigenetic mechanisms (Lesniak, 2011). Epigenetic mechanism hypomethylation of S100P gene involved in transcriptional regulation has been identified in pancreatic (Sato et al., 2004; Sato and Hitomi, 2002) and in prostate cancer (Wang et al., 2007) as well as in cervical carcinoma cells (Jakubickova et al., 2005). Inhibition of a DNA methylation by 5-aza- 2 ' -deoxycytidine (5-aza-dC) in S100P-negative cervical cell lines resulted in induced transcription of S100P.

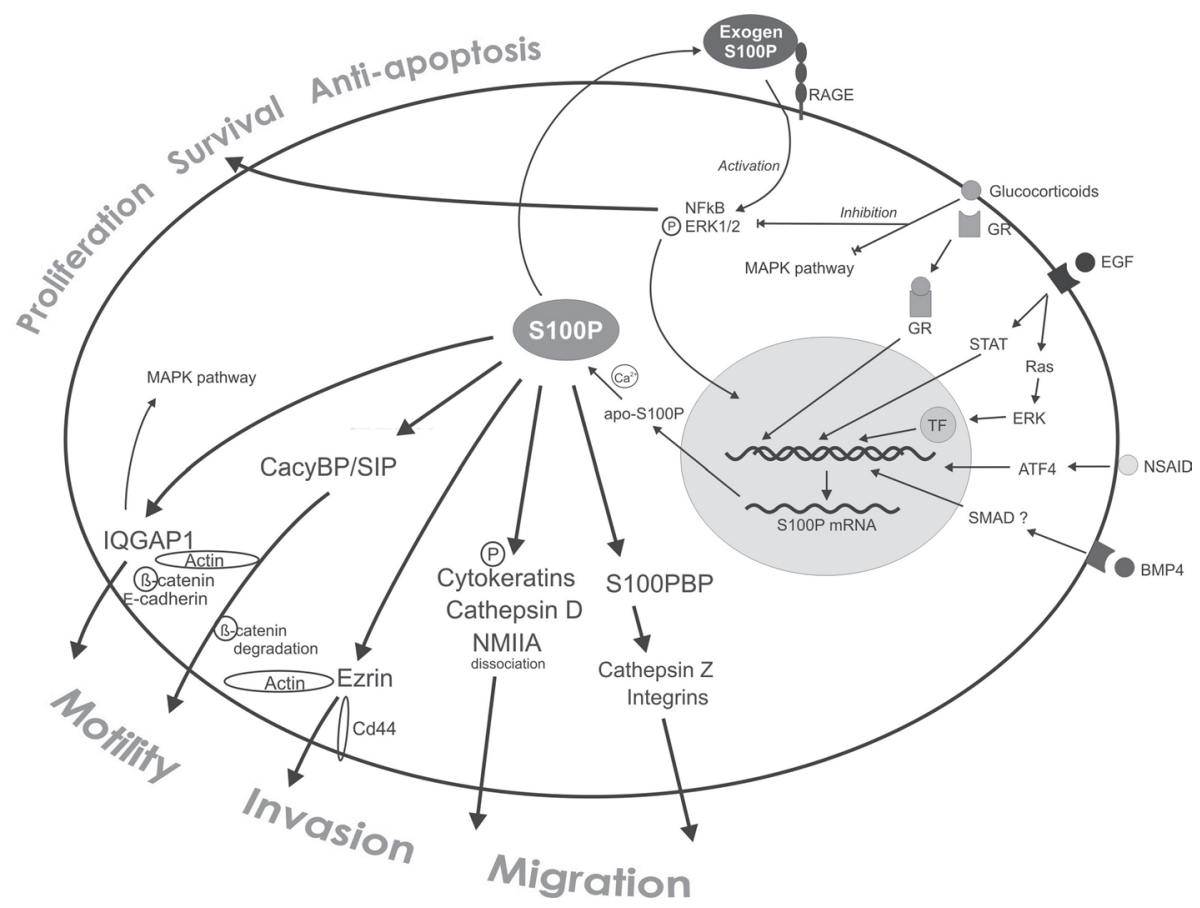

Fig. 1

S100P expression and modes of its action

Transcriptional regulation involves different pathways activated by hormones via intracellular GR (glucocorticoid receptor), by growth factors via corresponding transmembrane receptors (EGFR epidermal growth factor receptor, and BMPR bone morphogenic factor receptor) and by other pathways. Signals coming from these pathways appear to be transmitted through ERK1/2 (extracellular-signal regulated kinase) and mediated presumably by STAT, SMAD, and NFkB transcription factors. Secreted form of S100P can bind to extracellular ligand-binding site of RAGE (receptor for advanced glycation end-products), and via activation of ERK/MAPK pathway influences gene expression, cell proliferation and survival. Majority of intracellular S100P binding partners are proteins involved in cytoskeletal dynamics. The scaffolding proteins IQGAP1 and ezrin (a membrane/F-actin cross-linking protein) are known to promote cell motility and invasion. S100PBP mediates adhesion through regulation of Cathepsin Z and integrins and CacyBP/SIP is involved in $\beta$-catenin degradation. Physical interaction S100P with non-muscle myosin NMIIA molecules, regulation of protease Cathepsin D and alterations of the phosphorylation status of cytokeratins contribute to the increased cellular motility and ECM degradation. Up-regulated intracellular S100P seems to play a critical role in the maintenance of the cytoskeletal reorganization that leads to tissue disruption, as well as to acquisition of inappropriate migratory and invasive characteristics. 
Table 1. S100P expression in different stages and types of cancer

\begin{tabular}{|c|c|c|}
\hline Cancer type & Tumor progression, diagnostics, metastasis & References \\
\hline \multirow[t]{4}{*}{ Breast } & Early stages of cancer initiation & (Guerreiro Da Silva et al., 2000; Russo et al., 2001) \\
\hline & Association with high-risk lesions & (Schor et al., 2006) \\
\hline & $\begin{array}{l}\text { Significantly reduced survival and association with metastasis- } \\
\text { inducing proteins, metastasis in rat mammary model }\end{array}$ & (Wang et al., 2006) \\
\hline & High-grade breast tumors & (Dairkee et al., 2009) \\
\hline \multirow[t]{2}{*}{ Prostate } & Aggressive hormone-refractory tumors & (Amler et al., 2000; Mousses et al., 2002) \\
\hline & $\begin{array}{l}\text { Drug or a chemosensitization target, association with metas- } \\
\text { tasis }\end{array}$ & (Basu et al., 2008) \\
\hline \multirow[t]{3}{*}{ Pancreas } & $\begin{array}{l}\text { Early developmental marker, discriminating neoplastic disease } \\
\text { from chronic pancreatitis }\end{array}$ & $\begin{array}{l}\text { (Arumugam et al., 2005; Bournet et al., 2012; Cr- } \\
\text { nogorac-Jurcevic et al., 2003; Deng et al., 2008; Ohuch- } \\
\text { ida et al., 2006) }\end{array}$ \\
\hline & $\begin{array}{l}\text { Up-regulated expression, correlated significantly with increas- } \\
\text { ing grade }\end{array}$ & (Dowen et al., 2005) \\
\hline & Diagnostic accuracy in diagnosis and staging & (Dim et al., 2011; Kosarac et al., 2011) \\
\hline \multirow[t]{3}{*}{ Lung adenocarcinoma } & Diagnostic marker & (Kim et al., 2007) \\
\hline & Initial stage & (Rehbein et al., 2008) \\
\hline & Histopathological distinguish from other subtypes & (Watanabe et al., 2010) \\
\hline \multirow{2}{*}{$\begin{array}{l}\text { Non-small cell lung cancer } \\
\text { (NSCLC) }\end{array}$} & Early diagnostics & (Bartling et al., 2007; Diederichs et al., 2004) \\
\hline & Distant metastasis & (Bulk et al., 2008; Diederichs et al., 2004) \\
\hline Urothelial & $\begin{array}{l}\text { Distinction between urothelial carcinomas from other genitouri- } \\
\text { nary neoplasms }\end{array}$ & (Higgins et al., 2007) \\
\hline \multirow[t]{2}{*}{ Colorectal } & Differential diagnostics of flat adenomas & (Kita et al., 2006) \\
\hline & Hepatic metastasis & (Ding et al., 2011) \\
\hline Hepatocellular carcinoma & Contribution to the mitogenic potential of tumor cells & (Kim et al., 2009) \\
\hline \multirow[t]{2}{*}{ Cholangiocarcinoma } & Cytologic diagnostic marker & (Hamada et al., 2010) \\
\hline & Lymph node metastasis & (Aishima et al., 2011) \\
\hline Ovarian & Unfavourable outcome & (Surowiak et al., 2007) \\
\hline Oral & Anoikis resistance & (Kupferman et al., 2007) \\
\hline
\end{tabular}

\subsection{Promoter analysis}

Promoter study (5'-RACE mapping) defined the transcription initiation site 58 nt upstream of the first ATG codon. The 5 ' upstream region of the S100P gene contains the core promoter including the most important cis-regulatory elements with consensus sequences for transcription factors (STAT/CREB, SMAD, SP1/KLF, AP1,GR etc.) and accordingly, the promoter activity can be increased by EGF and hydrocortisone and decreased by inhibitors of SP-1, MAPK, and PI3K pathways (Gibadulinova et al., 2008). These regulatory elements are compatible with the cancer-related expression pattern of S100P gene, because they respond to signal transduction pathways that are frequently activated in tumors and crosstalk (Black et al., 2001; Kassel and Herrlich, 2007; Schoneveld et al., 2004).

Glucocorticoids have been widely used as components of chemotherapy regimens, however in non-haematological tumors, glucocorticoids display diverse and even contradictive effects in response to chemotherapy and are highly suspected of inducing resistance and increasing the frequency of metastases (Herr and Pfitzenmaier, 2006; Mattern et al., 2007; Moutsatsou and Papavassiliou, 2008).

Glucocorticoids exert their pleiotropic effects via the cross-talk between the glucocorticoid receptor and other signaling cascades and secondary messengers - a lot of local tissue factors such as growth factors, angiogenic/lymphogenic factors, apoptosis-related factors and cytokines are among the targets of GR signaling. S100P has also been found among GR transcriptional targets (Kino et al., 2009; Wang et al., 2004) and more detailed study has shown that dexamethasone (DX) induced activity of S100P promoter by means of increased expression, nuclear translocation, and transactivation properties of the glucocorticoid receptor (GR). Moreover, DX treatment led to decreased phosphorylation of ERK1/2, reduced transcriptional activity of AP1, and modulated activity of some additional transcription factors. GR binding region (containing GR elements, GREs) responsible for DX-mediated S100P transactivation is present in its proximal promoter and GR binding to this region was demonstrated by chromatin immunoprecipitation (Tothova et al., 2011). 
An intriguing feature of GREs, like other nuclear receptor binding regions, is that they are typically composite elements that encompass distinct sequence motifs recognized by two or more regulatory factors (So et al., 2007). So nuclear receptor binding regions are therefore enriched for binding sites for specific classes of transcription factors such as AP-1, Oct, Forkhead, ETS, STAT, and CREB. Functional studies have shown that nuclear receptor action on certain target genes is often dependent on the presence of specific factors. These observations thus reinforce the concept that nuclear receptor binding sites are only one part of complex multicomponent enhancers (Deblois and Giguere, 2008).

Surprising was the synergism of PD98059 inhibitor on the transcriptional activation of S100P and the mechanism of the crosstalk between GR and MAPK-mediated signaling acting on S100P promoter was proposed (Tothova et al., 2011). A similar potentiated effect on $S 100 \mathrm{P}$ expression was observed when the cells were treated with dexamethasone together with proteasome inhibitor (Kinyamu et al., 2008). PD98059, known as an MEK inhibitor (Alessi et al., 1995) also functions as a ligand and potent $\mathrm{AhR}$ antagonist (the AhR transcription factor is a key regulator of the cellular response to xenobiotic exposure). Recent findings indicate that both AhR and its heterodimerization partner ARNT are part of a multi-protein complex (cullin 4B ubiquitin ligase) involved in targeting proteins to the proteasome. Additionally, AhR ligands can interfere with hormonal signaling by targeting hormone receptors to the proteasome. Targeted degradation via the ubiquitin-proteasome pathway is one way by which the levels of nuclear hormone receptors are regulated (Swedenborg et al., 2009). Functional crosstalk between the AhR and GR has been reported, through which transactivation activity of the GR is further enhanced and in contrast, transactivation activity of the AhR is inhibited (Wang et al., 2009).

NSAIDs (non-steroidal anti-inflammatory drugs) in prolonged use have been revealed to reduce the risk of cancer. $\mathrm{S} 100 \mathrm{P}$ expression was up-regulated in human gastric carcinoma cells treated with various NSAIDs, including celecoxib (Namba et al., 2009). The celecoxib-mediated up-regulation of S100P was suppressed by the transfection of cells with small interfering RNA for activating transcription factor 4 (ATF4), a transcription factor involved in the endoplasmic reticulum stress response. Furthermore, deletion of ATF4 binding consensus sequence located in the promoter of the S100P gene resulted in inhibition of celecoxib mediated transcriptional activation of the gene.

Transcription of the S100P gene was activated by BMP4 (bone morphogenic protein) in a Smad-4 dependent manner (Hamada et al., 2009) and also in the presence of prostaglandin E2 (PGE2) in colon, breast and pancreatic cancer cells. Prostaglandin E2 (PGE2) levels are frequently elevated in colorectal carcinomas and interaction PGE2/EP4-receptor activates CREB via the ERK/MEK pathway. As the knockdown of CREB inhibits endogenous S100P expression, it may participate in feedback signaling that perpetuates tumor cell growth and migration with important consequences relevant to colon cancer pathogenesis (Chandramouli et al., 2010). Nonetheless, transcriptional regulation of S100P is very complicated and involves many signaling traits depending on stimulus, cell type, physiological context, levels of transcription factors, etc. From this point of view, it is difficult to propose how these pathways cross-talk and drive expression of S100P in different tumor types and situations.

\section{Future prospects}

Existing data collectively indicates that S100P protein is a functional component of cancer phenotype and that it could potentially serve as a diagnostic marker, prognostic/ predictive indicator and possibly also as a therapy target. This potential value is complicated by variations in S100P expression levels in different stages and types of cancer.

$\mathrm{S} 100 \mathrm{P}$ gene expression is subjected to complex regulation, but our knowledge is still insufficient to propose meaningful strategies for application. Better understanding of its elaborate regulation at the transcriptional level would allow for directed modulation of S100P levels via interference with upstream regulatory pathways.

In spite of this complicated background, some promising directions can already be seen at this stage. For example, upregulated S100P expression via glucocorticoids as well as NSAIDs treatment might provide useful information for cancer management. Interestingly, S100P transcription is also activated in a steroid-independent manner through ER stress-related ATF4 transcription factor binding to the core promoter of S100P (Namba et al., 2009). It has been proposed that in this case, the up-regulation of S100P might represent a protective cellular mechanism responsible for reduction of the therapeutic efficacy of NSAIDs. Since glucocorticoids repress both ATF4 (Adams, 2007) and ER stress response (Tothova et al., 2011), we can anticipate that steroid-dependent and independent pathways might operate on S100P promoter in a mutually exclusive or counterbalanced manner. Nevertheless, experimental evidence for this assumption remains to be acquired, since correlation between GR-S100P coexpression and tumor phenotype might provide useful predictive information and potentially result in better treatment planning.

Functional studies (mainly in pancreatic and colon cancer cells) of S100P indicate that its biological activities are exerted through extracellular signaling via RAGE receptor, resulting in increased proliferation and survival. Efforts to inhibit the interaction of S100P and RAGE create a basis of novel therapies for pancreatic cancer using small molecules 
(Arumugam et al., 2006). Recently, a number of specific short peptides (10-12 mers) derived from S100P have been examined, and some were found to bind with RAGE and block activation of this receptor by several of its ligands (Arumugam and Logsdon, 2011).

Cromolyn, which is widely used to treat allergic symptoms, was shown to bind with $\mathrm{S} 100 \mathrm{P}$ and thereby prevent its activation of RAGE. Also, the combination S100 inhibitors phenothiazine, chlorpromazine or W7 with cisplatin sensitized the drug resistant cell lines to apoptosis (Dairkee et al., 2009).

Finally, the role of S100P in cytoskeletal dynamics and cancer metastasis through interactions with ezrin, IQGAP1 etc., opens new horizons for future research.

Acknowledgement. We thank Professor Silvia Pastorekova, DrSc. for the critical reading of the manuscript. This work was supported by the grant from VEGA (2/0172/11) and by the Research \& Development Operational Program funded by the ERDF (ITMS 26240120027).

\section{References}

Adams CM, J. Biol. Chem. 282, 16744-16753, 2007. http://dx.doi. org/10.1074/jbc.M610510200

Aishima S, Fujita N, Mano Y, Kubo Y, Tanaka Y, Taketomi A, Shirabe K, Maehara Y, Oda Y, Am. J. Surg. Pathol. 35, 590-598, 2011. http://dx.doi.org/10.1097/PAS.0b013e31820ffdf1

Alessi DR, Cuenda A, Cohen P, Dudley DT, Saltiel AR, J. Biol. Chem. 270, 27489-27494, 1995. http://dx.doi.org/10.1074/ jbc.270.46.27489

Amler LC, Agus DB, LeDuc C, Sapinoso ML, Fox WD, Kern S, Lee D, Wang V, Leysens M, Higgins B, Martin J, Gerald W, Dracopoli N, Cordon-Cardo C, Scher HI, Hampton GM, Cancer Res. 60, 6134-6141, 2000.

Arumugam T, Logsdon CD, Amino Acids 41, 893-899,2011. http:// dx.doi.org/10.1007/s00726-010-0496-4

Arumugam T, Ramachandran V, Logsdon CD, J. Natl. Cancer Inst. 98, 1806-1818, 2006. http://dx.doi.org/10.1093/jnci/djj498

Arumugam T, Simeone DM, Schmidt AM, Logsdon CD, J. Biol. Chem. 279, 5059-5065, 2004. http://dx.doi.org/10.1074/ jbc.M310124200

Arumugam T, Simeone DM, Van Golen K, Logsdon CD, Clin. Cancer Res. 11, 5356-5364, 2005. http://dx.doi. org/10.1158/1078-0432.CCR-05-0092

Austermann J, Nazmi AR, Muller-Tidow C, Gerke V, J. Biol. Chem. 283, 29331-29340, 2008. http://dx.doi.org/10.1074/jbc. M806145200

Averboukh L, Liang P, Kantoff PW, Pardee AB, Prostate 29, 350-355, 1996. http://dx.doi.org/10.1002/(SICI)10970045(199612)29:6<350::AID-PROS2>3.0.CO;2-C

Barry S, Chelala C, Lines K, Sunamura M, Wang A, Marelli-Berg FM, Brennan C, Lemoine NR, Crnogorac-Jurcevic T, Clin. Exp. Metastasis, 2012

Bartling B, Rehbein G, Schmitt WD, Hofmann HS, Silber RE, Simm A, Eur. J. Cancer 43, 1935-1943, 2007. http://dx.doi. org/10.1016/j.ejca.2007.06.010
Basu GD, Azorsa DO, Kiefer JA, Rojas AM, Tuzmen S, Barrett MT, Trent JM, Kallioniemi O, Mousses S., Int. J. Cancer 123, 330-339, 2008. http://dx.doi.org/10.1002/ijc.23447

Becker T, Gerke V, Kube E, Weber K, Eur. J. Biochem. 207, 541 547, 1992. http://dx.doi.org/10.1111/j.1432-1033.1992. tb17080.x

Black AR, Black JD, Azizkhan-Clifford J, J. Cell. Physiol. 188, 143160, 2001. http://dx.doi.org/10.1002/jcp.1111

Bournet B, Pointreau A, Souque A, Oumouhou N, Muscari F, Lepage B, Senesse P, Barthet M, Lesavre N, Hammel P, Levy P, Ruszniewski P, Cordelier P, Buscail L, Pancreatology $12,27-34,2012$

Bulk E, Hascher A, Liersch R, Mesters RM, Diederichs S, Sargin B, Gerke V, Hotfilder M, Vormoor J, Berdel WE, Serve H, Muller-Tidow C, Cancer Res. 68, 1896-1904, 2008. http:// dx.doi.org/10.1158/0008-5472.CAN-07-2390

Crnogorac-Jurcevic T, Missiaglia E, Blaveri E, Gangeswaran R, Jones M, Terris B, Costello E, Neoptolemos JP, Lemoine NR, J. Pathol. 201, 63-74, 2003. http://dx.doi.org/10.1002/ path. 1418

Dairkee SH, Sayeed A, Luciani G, Champion S, Meng Z, Jakkula LR, Feiler HS, Gray JW, Moore DH, Cancer Res. 69, 7826-7834, 2009. http://dx.doi.org/10.1158/0008-5472. CAN-09-1564

Deblois G, Giguere V, Mol. Endocrinol. 22, 1999-2011, 2008. http:// dx.doi.org/10.1210/me.2007-0546

Deng H, Shi J, Wilkerson M, Meschter S, Dupree W, Lin F, Am. J. Clin. Pathol. 129, 81-88, 2008. http://dx.doi. org/10.1309/5D76NDE81LE8G545

Diederichs S, Bulk E, Steffen B, Ji P, Tickenbrock L, Lang K, Zanker KS, Metzger R, Schneider PM, Gerke V, Thomas M, Berdel WE, Serve H, Muller-Tidow C, Cancer Res. 64, 5564-5569, 2004. http://dx.doi.org/10.1158/0008-5472. CAN-04-2004

Dim DC, Jiang F, Qiu Q, Li T, Darwin P, Rodgers WH, Peng HQ, Diagn. Cytopathol., 2011.

Ding Q, Chang CJ, Xie X, Xia W, Yang JY, Wang SC, Wang Y, Xia J, Chen L, Cai C, Li H, Yen CJ, Kuo HP, Lee DF, Lang J, Huo L, Cheng X, Chen YJ, Li CW, Jeng LB, Hsu JL, Li LY, Tan A, Curley SA, Ellis LM, Dubois RN, Hung MC, J. Clin. Invest. 121, 4526-4536, 2011. http://dx.doi.org/10.1172/ LCI45008

Donato R, Microsc. Res. Tech. 60, 540-551, 2003. http://dx.doi. org/10.1002/jemt.10296

Donato R, Curr. Mol. Med. 7, 711-724, 2007. http://dx.doi. org/10.2174/156652407783220688

Dowen SE, Crnogorac-Jurcevic T, Gangeswaran R, Hansen M, Eloranta JJ, Bhakta V, Brentnall TA, Luttges J, Kloppel G, Lemoine NR, Am. J. Pathol. 166, 81-92, 2005. http:// dx.doi.org/10.1016/S0002-9440(10)62234-1

Du M, Wang G, Ismail TM, Gross S, Fernig DG, Barraclough R, Rudland PS, J. Biol. Chem., 2012.

Emoto Y, Kobayashi R, Akatsuka H, Hidaka H, Biochem. Biophys. Res. Commun. 182, 1246-1253, 1992. http://dx.doi. org/10.1016/0006-291X(92)91865-N

Erickson JW, Cerione RA, Hart MJ, J. Biol. Chem. 272, 24443-24447, 1997. http://dx.doi.org/10.1074/jbc.272.39.24443 
Filipek A, Jastrzebska B, Nowotny M, Kuznicki J, J. Biol. Chem. 277, 28848-28852, 2002. http://dx.doi.org/10.1074/jbc. M203602200

Fuentes MK, Nigavekar SS, Arumugam T, Logsdon CD, Schmidt AM, Park JC, Huang EH, Dis. Colon Rectum 50, 12301240, 2007 http://dx.doi.org/10.1007/s10350-006-0850$\underline{5}$

Gerke V, Weber K, EMBO J. 4, 2917-2920, 1985.

Gibadulinova A, Oveckova I, Parkkila S, Pastorekova S, Pastorek J, Oncol. Rep. 20, 391-396, 2008.

Guerreiro Da Silva ID, Hu YF, Russo IH, Ao X, Salicioni AM, Yang X, Russo J, Int. J. Oncol. 16, 231-240, 2000.

Gulmann C, Paner GP, Parakh RS, Hansel DE, Shen SS, Ro JY, Annaiah C, Lopez-Beltran A, Rao P, Arora K, Cho Y, Herrera-Hernandez L, Alsabeh R, Amin MB, Hum. Pathol., 2012.

Hamada S, Satoh K, Hirota M, Fujibuchi W, Kanno A, Umino J, Ito H, Satoh A, Kikuta K, Kume K, Masamune A, Shimosegawa T, Cancer Sci. 100, 103-110, 2009. http://dx.doi. org/10.1111/j.1349-7006.2008.00993.x

Hamada S, Satoh K, Hirota M, Kanno A, Ishida K, Umino J, Ito H, Kikuta K, Kume K, Masamune A, Katayose Y, Unno M, Shimosegawa T, Cancer Sci. 102, 150-156, 2010. http:// dx.doi.org/10.1111/j.1349-7006.2010.01757.x

Heil A, Nazmi AR, Koltzscher M, Poeter M, Austermann J, Assard N, Baudier J, Kaibuchi K, Gerke V, J. Biol. Chem. 286, 7227-7238, 2011. http://dx.doi.org/10.1074/jbc. $\underline{M 110.135095}$

Herr I, Pfitzenmaier J, Lancet Oncol. 7, 425-430, 2006. http://dx.doi. org/10.1016/S1470-2045(06)70694-5

Higgins JP, Kaygusuz G, Wang L, Montgomery K, Mason V, Zhu SX, Marinelli RJ, Presti JC Jr, van de Rijn M, Brooks JD, Am. J. Surg. Pathol. 31, 673-680, 2007. http://dx.doi. org/10.1097/01.pas.0000213438.01278.5f

Ho YD, Joyal JL, Li Z, Sacks DB, J. Biol. Chem. 274, 464-470, 1999. http://dx.doi.org/10.1074/jbc.274.1.464

Hofmann MA, Drury S, Fu C, Qu W, Taguchi A, Lu Y, Avila C, Kambham N, Bierhaus A, Nawroth P, Neurath MF, Slattery T, Beach D, McClary J, Nagashima M, Morser J, Stern D, Schmidt AM, Cell 97, 889-901, 1999. http://dx.doi. org/10.1016/S0092-8674(00)80801-6

Hunter KW, Trends Mol. Med. 10, 201-204, 2004. http://dx.doi. org/10.1016/j.molmed.2004.03.001

Chandramouli A, Mercado-Pimentel ME, Hutchinson A, Gibadulinova A, Olson ER, Dickinson S, Shanas R, Davenport J, Owens J, Bhattacharyya AK, Regan JW, Pastorekova S, Arumugam T, Logsdon CD, Nelson MA, Cancer Biol. Ther. 10, 1056-1066, 2010. http://dx.doi. org/10.4161/cbt.10.10.13373

Ivetic A, Ridley AJ, Immunology 112, 165-176, 2004. http://dx.doi. org/10.1111/j.1365-2567.2004.01882.x

Jakubickova L, Barathova M, Pastorekova S, Pastorek J, Gibadulinova A, Acta Virol. 49, 133-137, 2005.

Jia SQ, Niu ZJ, Zhang LH, Zhong XY, Shi T, Du H, Zhang GG, Hu Y, Su XL, Ji JF, J. Cancer Res. Clin. Oncol. 135, 403-411, 2009. http://dx.doi.org/10.1007/s00432-008-0474-3

Kassel O, Herrlich P, Mol. Cell. Endocrinol. 275, 13-29, 2007. http:// dx.doi.org/10.1016/j.mce.2007.07.003
Kim B, Lee HJ, Choi HY, Shin Y, Nam S, Seo G, Son DS, Jo J, Kim J, Lee J, Kim K, Lee S, Cancer Res. 67, 7431-7438, 2007. http://dx.doi.org/10.1158/0008-5472.CAN-07-0003

Kim JK, Jung KH, Noh JH, Eun JW, Bae HJ, Xie HJ, Ahn YM, Ryu JC, Park WS, Lee JY, Nam SW, Int. J. Oncol. 35, 12571264, 2009.

Kino T, Manoli I, Kelkar S, Wang Y, Su YA, Chrousos GP, Biochem. Biophys. Res. Commun. 381, 671-675, 2009. http://dx.doi. org/10.1016/j.bbrc.2009.02.110

Kinyamu HK, Collins JB, Grissom SF, Hebbar PB, Archer TK, Mol. Carcinog. 47, 845-885, 2008. http://dx.doi.org/10.1002/ mc. 20440

Kita H, Hikichi Y, Hikami K, Tsuneyama K, Cui ZG, Osawa H, Ohnishi H, Mutoh H, Hoshino H, Bowlus CL, Yamamoto H, Sugano K, J. Gastroenterol. 41, 1053-1063, 2006. http:// dx.doi.org/10.1007/s00535-006-1894-y

Koltzscher M, Neumann C, Konig S, Gerke V, Mol. Biol. Cell 14, 2372-2384, 2003. http://dx.doi.org/10.1091/mbc.E0209-0553

Kosarac O, Takei H, Zhai QJ, Schwartz MR, Mody DR, Acta Cytol. 55, 142-148, 2011. http://dx.doi.org/10.1159/000320913

Kupferman ME, Patel V, Sriuranpong V, Amornphimoltham P, Jasser SA, Mandal M, Zhou G, Wang J, Coombes K, Multani A, Pathak S, Silvio Gutkind J, Myers JN, Oral Oncol. 43, 440-454, 2007. http://dx.doi.org/10.1016/j. oraloncology.2006.04.016

Lesniak W, Clin. Epigenetics 2, 77-83, 2011. http://dx.doi. org/10.1007/s13148-011-0023-9

Lines KE, Chelala C, Dmitrovic B, Wijesuriya N, Kocher HM, Marshall JF, Crnogorac-Jurcevic T, Am. J. Pathol. 180, 1485-1494, 2012. http://dx.doi.org/10.1016/j.ajpath.2011.12.031

Mahalingam D, Kong CM, Lai J, Tay LL, Yang H, Wang X, Sci. Rep. 2, 592, 2012. http://dx.doi.org/10.1038/srep00592

Matsuzawa SI, Reed JC, Mol. Cell 7, 915-926, 2001. http://dx.doi. org/10.1016/S1097-2765(01)00242-8

Mattern J, Buchler MW, Herr I, Cancer Biol. Ther. 6, 1345-1354, 2007. http://dx.doi.org/10.4161/cbt.6.9.4765

McCabe MT, Brandes JC, Vertino PM, Clin. Cancer Res., 2009.

Meng Y, Lu Z, Yu S, Zhang Q, Ma Y, Chen J, J. Transl. Med. 8, 61, 2010. http://dx.doi.org/10.1186/1479-5876-8-61

Moore BW, Biochem. Biophys. Res. Commun. 19, 739-744, 1965. http://dx.doi.org/10.1016/0006-291X(65)90320-7

Mousses S, Bubendorf L, Wagner U, Hostetter G, Kononen J, Cornelison R, Goldberger N, Elkahloun AG, Willi N, Koivisto P, Ferhle W, Raffeld M, Sauter G, Kallioniemi OP, Cancer Res. 62, 1256-60, 2002.

Moutsatsou P, Papavassiliou AG, J. Cell. Mol. Med. 12, 145-163, 2008. http://dx.doi.org/10.1111/j.1582-4934.2007.00177.x

Namba T, Homan T, Nishimura T, Mima S, Hoshino T, Mizushima T, J. Biol. Chem. 284, 4158-67, 2009. http://dx.doi. org/10.1074/jbc.M806051200

Ohuchida K, Mizumoto K, Ohhashi S, Yamaguchi H, Konomi H, Nagai E, Yamaguchi K, Tsuneyoshi M, Tanaka M, Clin. Cancer Res. 12, 5417-5422, 2006. http://dx.doi. org/10.1158/1078-0432.CCR-06-0222

Parkkila S, Pan PW, Ward A, Gibadulinova A, Oveckova I, Pastorekova S, Pastorek J, Martinez AR, Helin HO, Isola J, BMC 
Clin. Pathol. 8, 2, 2008. http://dx.doi.org/10.1186/14726890-8-2

Permyakov SE, Ismailov RG, Xue B, Denesyuk AI, Uversky VN, Permyakov EA, Mol. Biosyst. 7, 2164-2180, 2011. http:// dx.doi.org/10.1039/c0mb00305k

Raspollini MR, Comin CE, Crisci A, Chilosi M, Pathologica 102, 33-5, 2010.

Rehbein G, Simm A, Hofmann HS, Silber RE, Bartling B, Int. J. Mol. Med. 22, 69-77, 2008.

Rezvanpour A, Shaw GS, Gen. Physiol. Biophys. 28 Spec No Focus, F39-46, 2009.

Rossy J, Gutjahr MC, Blaser N, Schlicht D, Niggli V, Exp. Cell Res. 313, 1106-1120, 2007. http://dx.doi.org/10.1016/j. yexcr.2006.12.023

Russo J, Hu YF, Silva ID, Russo IH, Microsc. Res. Tech. 52, 204-223, 2001. http://dx.doi.org/10.1002/10970029(20010115)52:2<204::AID-JEMT1006>3.0.CO;2-F

Sato N, Fukushima N, Matsubayashi H, Goggins M, Oncogene 23, 1531-8, 2004. http://dx.doi.org/10.1038/sj.onc.1207269

Sato N, Hitomi J, Anat. Rec. 267, 60-69, 2002. http://dx.doi. org/10.1002/ar.10085

Shang X, Cheng H, Zhou R, Genet. Sel. Evol. 40, 449-464, 2008.

Schoneveld OJ, Gaemers IC, Lamers WH, Biochim. Biophys. Acta 1680, 114-128, 2004. http://dx.doi.org/10.1016/j. bbaexp.2004.09.004

Schor AP, Carvalho FM, Kemp C, Silva ID, Russo J, Oncol. Rep. 15, 3-6, 2006.

So AY, Chaivorapol C, Bolton EC, Li H, Yamamoto KR, PLoS Genet. 3, e94, 2007. http://dx.doi.org/10.1371/journal. pgen.0030094

Surowiak P, Maciejczyk A, Materna V, Drag-Zalesinska M, Wojnar A, Pudelko M, Kedzia W, Spaczynski M, Dietel M, Zabel
M, Lage H, Histopathology 51, 125-128, 2007. http:// dx.doi.org/10.1111/j.1365-2559.2007.02714.x

Swedenborg E, Ruegg J, Makela S, Pongratz I, J. Mol. Endocrinol. 43, 1-10, 2009. http://dx.doi.org/10.1677/JME-08-0132

Tothova V, Isola J, Parkkila S, Kopacek J, Pastorek J, Pastorekova S, Gibadulinova A, J. Cell. Biochem. 112, 3373-3384, 2011. http://dx.doi.org/10.1002/jcb.23268

Tsai JH, Huang WC, Kuo KT, Yuan RH, Chen YL, Jeng YM, Histopathology 61, 1106-1116, 2012. http://dx.doi. org/10.1111/j.1365-2559.2012.04316.x

Wang G, Platt-Higgins A, Carroll J, de Silva Rudland S, Winstanley J, Barraclough R, Rudland PS, Cancer Res. 66, 1199-1207, 2006. http://dx.doi.org/10.1158/0008-5472. CAN-05-2605

Wang H, Wang Y, Rayburn ER, Hill DL, Rinehart JJ, Zhang R, Int. J. Oncol. 30, 947-953, 2007.

Wang JC, Derynck MK, Nonaka DF, Khodabakhsh DB, Haqq C, Yamamoto KR, Proc. Natl. Acad. Sci. U S A 101, 15603-15608, 2004. http://dx.doi.org/10.1073/ pnas.0407008101

Wang SH, Liang CT, Liu YW, Huang MC, Huang SC, Hong WF, Su JG, Toxicology 262, 87-97, 2009. http://dx.doi. org/10.1016/j.tox.2009.03.020

Watanabe T, Miura T, Degawa Y, Fujita Y, Inoue M, Kawaguchi M, Furihata C, Cancer Cell Int. 10, 2, 2010. http://dx.doi. org/10.1186/1475-2867-10-2

Whiteman HJ, Weeks ME, Dowen SE, Barry S, Timms JF, Lemoine NR, Crnogorac-Jurcevic T, Cancer Res. 67, 8633-8642, 2007. http://dx.doi.org/10.1158/0008-5472.CAN-07$\underline{0545}$

Youn JY, Wang T, Cai H, Circ. Res. 104, 50-59, 2009. http://dx.doi. org/10.1161/CIRCRESAHA.108.178467 